\title{
BRIEF COMMUNICATIONS \\ Molecular data confirm the validity of the Portuguese blenny (Parablennius ruber, Valenciennes, 1836) and its presence in Western Europe
}

\author{
V. C. Almada*†, V. S. Domingues*†, N. M. Monteiro*\&\|, \\ F. Almada* and R. S. Santos: \\ *Instituto Superior de Psicologia Aplicada, Unidade de Investigação em Eco-Etologia, \\ R. Jardim do Tabaco 34, 1149-041 Lisboa, Portugal, †Departamento de Oceanografia e \\ Pescas, Universidade dos Açores, 9901-862 Horta, Azores, Portugal, §Faculdade de \\ Ciências da Saúde, Universidade Fernando Pessoa, Rua Carlos da Maia, 296, \\ 4200-150 Porto, Portugal, ||CIIMAR, Centro Interdisciplinar de Investigação \\ Marinha e Ambiental, Rua dos Bragas 177, 4050-123 Porto, Portugal and \\ IInstituto de Oceanografia, Faculdade de Ciências da Universidade de \\ Lisboa, Campo Grande, 1749-016 Lisboa, Portugal
}

(Received 31 January 2006, Accepted 22 September 2006)

\begin{abstract}
DNA sequence analysis confirms the distinction between Parablennius ruber and Parablennius gattorugine, simultaneously validating the presence of the former species in Western Europe where it has been reported for $>150$ years. A possible scenario involving speciation of $P$. ruber at the Azores and subsequent transport of larvae to Europe, a process that may be still occurring nowadays, could explain this pattern of occurrence.

(C) 2007 The Authors

Journal compilation 12007 The Fisheries Society of the British Isles
\end{abstract}

Key words: Northeastern Atlantic; biogeography; Blenniidae; mitochondrial ribosomal DNA; speciation.

The Portuguese blenny (Parablennius ruber, Valenciennes, 1836) is a blenniid fish, which constitutes a major element of the rocky subtidal ichthyofauna of the Azores (Santos, 1987; Azevedo \& Homem, 2002). Almada et al. (2005) showed, based on molecular data, that $P$. ruber is a sister species of Parablennius gattorugine (Linnaeus, 1758), with which it forms a very differentiated clade within the genus Parablennius. The similarity between the two species is so strong that, although described in the 19 century (Valenciennes, 1836), for many years, the validity of $P$. ruber was questioned and it was often not distinguished from $P$. gattorugine. The species was revalidated independently by Bath (1982) and by Almeida (1982). Both the authors showed that P. ruber differs from $P$. gattorugine in a number of morphological traits that include the morphology

$\dagger$ †uthor to whom correspondence should be addressed. Tel.: +351 218811700; fax: +351 218860954; email: valmada@netcabo.pt 
of the lateral line system and the shape of the orbital tentacles (Fig. 1). Surprisingly, although the species was commonly viewed as a fish from the Macaronesian Islands, both the original description of Valenciennes (1836) and the revalidation by Almeida (1982) were based on material collected in the shores of mainland Europe, from the western coast of France to the southern coast of Portugal. This is remarkable because P. gattorugine is quite abundant in both the Atlantic and the Mediterranean shores of Europe. The finding of these specimens of $P$. ruber indicates that, at least from the time of Valenciennes (1836), $P$. ruber is sympatric with $P$. gattorugine although surveys of European littoral fishes very rarely report its presence. In recent years, the presence of this species in the shores of western Britain and Ireland became clearly noted (pictures and records available at http://www.habitas.org.uk/marinelife/species.asp?item=ZG6370; B. Picton, pers. comm.). One of these pictures was also examined by P. Wirtz (pers. comm.) who also confirmed the identification.

Two distinct issues are addressed within this note: first, using the mitochondrial $12 \mathrm{~S}$ and $16 \mathrm{~S}$ rDNA, Azorean $P$. ruber samples are compared with those of $P$. gattorugine from the Mediterranean and from the Atlantic shores of Europe, in order to test, using molecular data, the consistency of the distinction between the two species as suggested by their morphologies. Additionally, the DNA of fish morphologically classified as $P$. ruber and caught in Northwest Portugal was compared both with material from $P$. gattorugine and with Azorean samples of $P$. ruber. This comparison was made to test the hypothesis that the morphological similarities between continental and insular fish classified as $P$. ruber reflect true genetic affinity.

Samples of $P$. ruber were collected from the Azores (Faial $38^{\circ} 40^{\prime} \mathrm{N} ; 27^{\circ} 10^{\prime} \mathrm{W}$, eight specimens, PRAZ1-PRAZ8) and from the northwest coast of mainland Portugal (Moledo do Minho, Caminha $41^{\circ} 50^{\prime} \mathrm{N} ; 8^{\circ} 50^{\prime} \mathrm{W}$, three specimens, PRMM1-PRMM3). Samples of P. gattorugine were collected from mainland Portugal (S. Pedro do Estoril, Cascais $38^{\circ} 41^{\prime} \mathrm{N} ; 09^{\circ} 25^{\prime} \mathrm{W}$, eight specimens, PGSP1-PGSP8), England (Plymouth $50^{\circ} 25^{\prime} \mathrm{N} ; 04^{\circ} 05^{\prime} \mathrm{W}$, one specimen, PGEN1), the Mediterranean from Eastern Italy (Chioggia $45^{\circ} 13^{\prime} \mathrm{N}$; $12^{\circ} 17^{\prime}$ E, two specimens, PGIT1 and PGIT2) and Eastern Greece (Lavrio

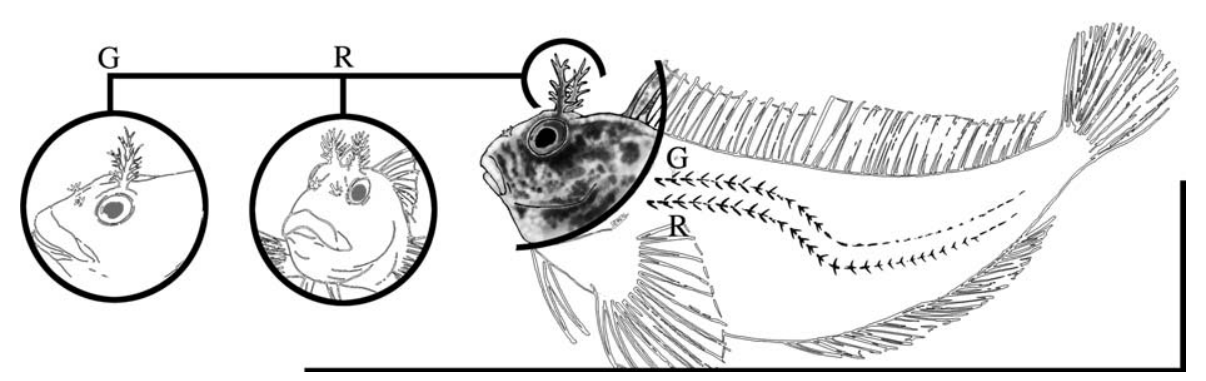

FIG. 1. Diagrammatic representation outlining the more salient differences between Parablennius gattorugine $(\mathrm{G})$ and Parablennius ruber $(\mathrm{R})$. The differences at the level of the orbital tentacles and the lateral line are especially conspicuous. In $P$. ruber the supraorbital tentacles tend to be bilobed, the main stem is short with many branches arising almost at the same level. In P. gattorugine there is a central stem along which thinner branches arise at different levels. The shape of the supraorbital tentacles is, however, quite variable in P. gattorugine. 
$37^{\circ} 42^{\prime} \mathrm{N} ; 2^{\circ} 04^{\prime} \mathrm{E}$, one specimen, PGGR1). Sequences are available at GenBank under accession numbers AY098778, AY098779, AY098834, AY098835 and DQ160198-DQ160205. The voucher specimens are deposited in the fish collection of the Eco-Ethology Research Unit at the Instituto Superior de Psicologia Aplicada, Lisbon. Parablennius pilicornis (Cuvier, 1829) and Parablennius sanguinolentus (Pallas 1814) were used as out-groups (GenBank accession numbers AY098796, AY098831, AF414700 and AY345187). Fin clips were cut immediately after collection of the individuals and stored at ambient temperature in $96 \%$ ethanol. Total genomic DNA was extracted from fin rays using a proteinase $\mathrm{K} /$ sodium dodecyl sulphate (SDS) based extraction buffer following the Sambrook et al. (1989) protocol.

Fragments of the $12 \mathrm{~S}$ and $16 \mathrm{~S}$ rDNA were amplified using primers described in Henriques et al. (2002), and polymerase chain reaction and sequencing conditions described in Almada et al. (2005). Sequence alignments were made using ClustalX 1.81 (Thompson et al., 1997) with default settings. Character congruence between the two fragments was tested using the incongruence-length difference test (Farris et al., 1995) available in PAUP (version 4.0; Swofford, 1998). The null hypothesis of congruence between the two data sets was not rejected $(P=1)$, which led us to analyse the $12 \mathrm{~S}$ and $16 \mathrm{~S}$ rDNA sequences combined in one single fragment.

Phylogenetic relationships were assessed using maximum parsimony (MP) and neighbour-joining (NJ) methods, implemented by the software package PAUP. Bootstrapping (Felsenstein, 1985) was used to assess robustness of the nodes in the trees with 1000 replicates. As the authors were dealing with very closely related species with very small genetic distances, patristic distances were adopted (following Nei \& Kumar, 2000). An analysis of molecular variance (AMOVA; Excoffier et al., 1997) was performed using ARLEQUIN 2.0 (Schneider et al., 2000), to test the genetic differentiation between the samples of $P$. ruber and $P$. gattorugine.

A total of $367 \mathrm{bp}$ of the mitochondrial $12 \mathrm{~S}$ rDNA and $480 \mathrm{bp}$ of the mitochondrial 16S rDNA were analysed, resulting in a combined sequence of 847 bp. In Fig. 2, the results of the phylogenetic analysis are summarized. A single phylogenetic MP tree of 139 steps was recovered and had the same topology as the NJ tree. Parablennius ruber and P. gattorugine form a monophyletic clade clearly separated from the other species of the genus Parablennius used as out-groups. All samples of $P$. gattorugine form a well-supported clade, which is sister to another equally well-supported clade that contains all $P$. ruber samples. The samples from mainland Portugal, group unambiguously with the Azorean samples of $P$. ruber. The mean interspecific uncorrected $p$ distances are $1.67 \%$ (S.D. $=0 \cdot 12 \%$ ) and $1.71 \%$ (S.D. $=0 \cdot 14 \%$ ) for $12 \mathrm{~S}$ and $16 \mathrm{~S}$, respectively. The intraspecific distances are $0.91 \%$ (S.D. $=0.17 \%$ ) and $0 \cdot 11 \%$ (S.D. $=$ $0 \cdot 17 \%$ ) for $P$. ruber $(12 \mathrm{~S}$ and $16 \mathrm{~S}$, respectively), and $0 \%$ (S.D. $=0 \%$ ) and $0.096 \%$ (S.D. $=0 \cdot 11 \%$ ) for $P$. gattorugine $(12 \mathrm{~S}$ and $16 \mathrm{~S}$, respectively).

The AMOVA analysis showed that $84.99 \%$ of the total genetic variation was due to interspecific differences, while the intraspecific variation accounted for $15 \cdot 01 \%$. The fixation index was highly significant $(P=0)$ for 1023 permutations.

The results presented in this study provide molecular support for the distinction between $P$. ruber and $P$. gattorugine. They also demonstrate that $P$. ruber is present both in the Azores and in the northwestern shore of mainland Portugal. This conclusion could be criticized due to the fact that the molecular markers 


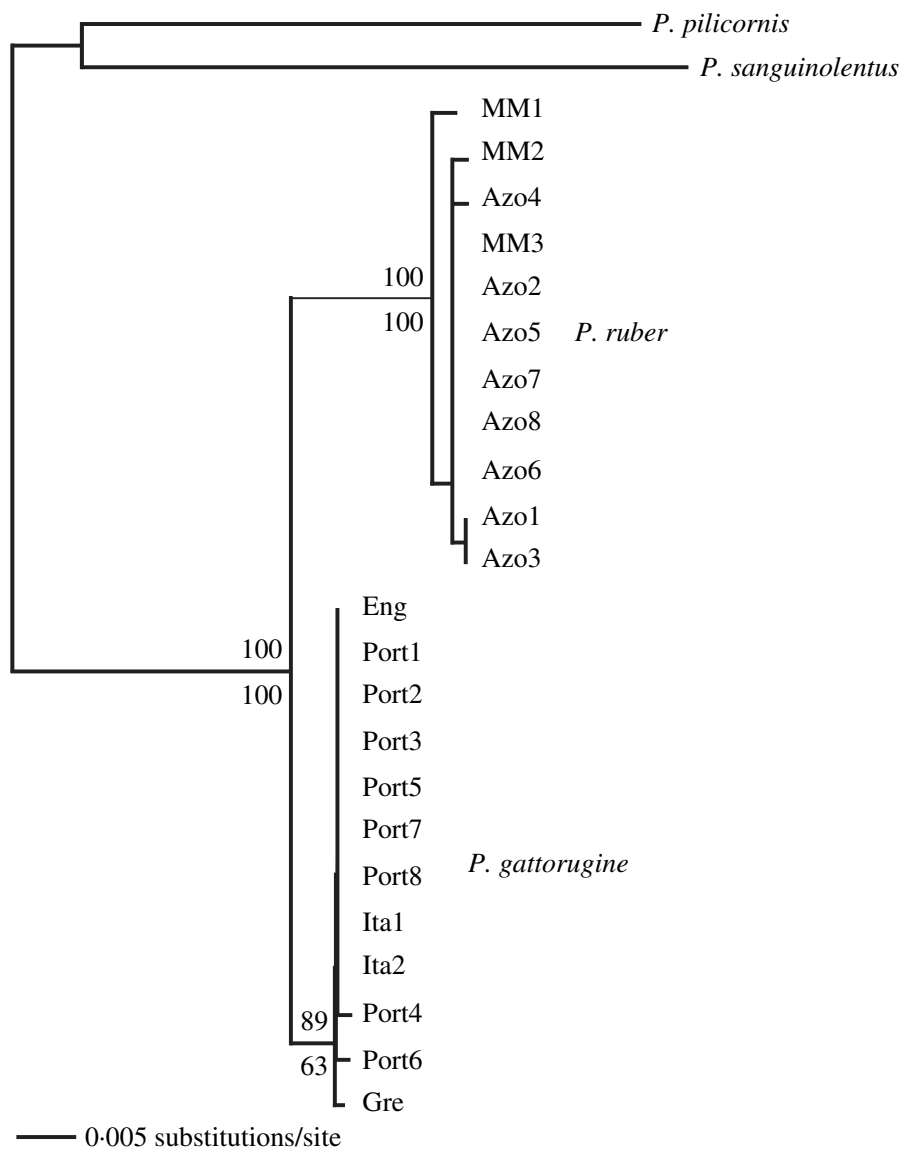

FIG. 2. Phylogenetic relationship of Parablennius ruber and Parablennius gattorugine using Parablennius pilicornis and Parablennius sanguinolentus as out-groups. A neighbour-joining tree is shown with neighbour-joining (above the nodes) and maximum parsimony (below the nodes) bootstrap support at the major nodes. Labels are: MM (Moledo do Minho, Northern Portugal), Azo (Azores), Port (Southern Portugal), Eng (Plymouth, England), Ita (Italy), Gre (Greece). The length of each branch is proportional to the number of nucleotide substitutions.

used are maternally inherited, and the presence of hybrids could not be excluded. This possibility seems unlikely as all the specimens, from both mainland Europe and Azores, all genetically classified as $P$. ruber, were unequivocally assigned to the same species based on all available morphological diagnostic criteria.

In recent years, many warm water organisms have been recorded in European waters for the first time, while the distribution of others have shifted, tracking changes in sea surface temperatures (Southward et al., 1995; Kröncke et al., 1998; O'Brien et al., 2000). In the case of $P$. ruber, it is interesting that the original description by Valenciennes (1836) was based on specimens from the western coast of France, which means that this species already occurred in Europe more than one and a half century ago. The material included by Almeida (1982), in his revalidation of the species, was from northwest Portugal and from Algarve, in the south of the country. Bath (1982) used material from Azores and from 
Madeira, implying that the species was also found at these archipelagos. Recent surveys (N. Monteiro, unpubl. data), on the shore of Madeira, could not detect $P$. ruber, suggesting that the species may now be uncommon at this archipelago. Concerning the presence of $P$. ruber in the Atlantic shores of Western Europe, the issue that requires clarification is the apparent contradiction between the relatively old presence of this species in Europe and its rarity or absence in most surveys of fishes of the European rocky shores. One has to admit the possibility that the species was not recorded because of insufficient sampling or inadequate identification. This seems, however, unlikely for areas like the British Isles where thorough surveys of the inshore ichthyofauna have been conducted for many years. Thus, the possibility that $P$. ruber is regularly present on the west European shores, although at low numbers should not be ruled out. If it occurs in very small numbers, it is possible that $P$. ruber may not be able to establish viable populations in Europe. The authors suggest that these populations may be, to a considerable extent, replenished by occasional larval transport from the Azores. The idea that blenniid larvae are able to undergo long distance transport was already proposed by Muss et al. (2001) to explain the distribution of Ophioblennius atlanticus (Valenciennes, 1836) across the Atlantic Ocean. Rafting on algae is another form of long distance transport that was demonstrated for blenniids. Specimens of Hypleurochilus fissicornis (Quoy \& Gaimard, 1824), a species living in the southwestern Atlantic, were collected from a raft, off Azores (Santos et al., 1997), a transport that involves a much greater distance that the one between Azores and Western Europe.

Azevedo \& Homem (2002) showed that, at the Azores, P. ruber breeds in winter, the time when winds blowing from southwest are stronger, maximizing the likelihood of larval transport from the Azores to Western Europe. Thus, $P$. ruber may be a species conforming to the model of blenniid speciation proposed by Zander (1973, 1980). According to this model, blenniids transported from the European shores, could sometimes reach the Atlantic Islands where they could survive the glacial periods undergoing some degree of independent evolution to become incipient new species. These new species would then be transported back to Europe by the predominant currents and, if reproductive isolation was sufficiently strong, could become a new component of the European ichthyofauna, when temperatures become more favourable. The idea that the Macaronesian Islands like the Madeira and the Azores were colonized from eastern Atlantic sources is supported by the fact that from the eight blenniid species found at the Azores, six were 'Lusitanian'. They are shared with the warm temperate eastern Atlantic shores of Europe and Africa extending in most cases into the Mediterranean. One species (O. atlanticus) is shared with the tropical Africa and the tropical western Atlantic, and another (Parablennius parvicornis, Valenciennes, 1836) occurs in the Macaronesia and in the tropical Africa. The situation of the blenniid fauna of Madeira is very similar and many Azorean fish probably derived from a Madeiran source (Santos et al., 1995). Thus, at least in the past, it is certain that blenniids dispersed from the eastern Atlantic shores to the Macaronesian Islands (Almada et al., 2001). Such a scenario may well apply to $P$. ruber. It very likely derived from a $P$. gattoruginelike ancestor that colonized the Azores. It may have evolved there, surviving for one or more glacial periods. During glacial peeks, the Atlantic shores of 
Europe became so cold, that most blenniid species were probably extirpated. Indeed, Dias et al. (1997) showed that at the last glacial maximum, the sea surface temperatures along the western coast of Portugal were many degrees lower than today and the polar front was located south of Lisbon. Neither P. gattorugine nor $P$. ruber are found in these subpolar conditions. On the contrary, in the Azores, the drop in sea surface temperature was only of $c .3^{\circ} \mathrm{C}$, corresponding to a temperature similar to that found nowadays in Western European shores (Crowley, 1981). If the scenario outlined above applies to $P$. ruber, it may well be that the increase in occurrences reported by B. Picton (pers. comm.) for the British Isles may represent the effects of increasing water temperatures, which would favour the survival and reproduction of a species that, coming from the Azores, probably requires warmer waters than $P$. gattorugine to breed successfully. It may also represent increased transport promoted by circulation coming from the southwest. The apparent decrease, or even disappearance, of the species in lower latitudes, as in Madeira, may be related to increasing temperatures to levels above the upper range for the species. The same seems to be occurring with Lipophrys pholis (Linnaeus, 1758). In Madeira, and also in the Azores and in the Canaries, new additions to the marine fauna originating from southern latitudes are noticeable (Wirtz, 1998; Azevedo et al., 2004).

More intensive surveys of the western European fish assemblages combined with more intensive genetic sampling are required to test this hypothesis. It is particularly necessary to clarify to what extent $P$. ruber is able to breed in European waters and the extent of its isolation from the much more abundant $P$. gattorugine.

This study was funded by Plurianual Program (Fundação para a Ciência e Tecnologia, FCT), UI\&Ds 331 and 531, partially FEDER funded, and PNAT 1999/BIA/15017. V.S.D. has a PhD grant SFRH/BD/13069/2003, N.M.M. has a post-doc grant SFRH/ BPD/14992/2004 and F.A. has a PhD grant PRAXIS XXI/BD/11178/97 from the Portuguese Foundation for Science and Technology. We would like to thank B. Picton and P. Wirtz for their personal communications.

\section{References}

Almada, F., Almada, V., Guillemaud, T. \& Wirtz, P. (2005). Phylogenetic relationships of the north-eastern Atlantic and Mediterranean blenniids. Biological Journal of the Linnean Society 86, 283-295.

Almada, V. C., Gonçalves, E. J., Oliveira, R. F., Almeida, A. J., Santos, R. S. \& Wirtz, P. (2001). Patterns of diversity of the north-eastern Atlantic blenniid fish fauna (Pisces: Blenniidae). Global Ecology and Biogeography 10, 411-422.

Almeida, A. J. (1982). Sur la presence de Blennius ruber Valenciennes, 1836 aux Açores (Pisces: Blenniidae). Cybium 6, 35-40.

Azevedo, J. M. N. \& Homem, N. (2002). Age and growth, reproduction and diet of the red blenny Parablennius ruber (Blenniidae). Cybium 26, 129-133.

Azevedo, J. M. N., Raposeiro, P. M. \& Rodrigues, L. (2004). First records of Fistularia petimba and Diodon eydouxii for the Azores, with notes on the occurrence of three additional species. Journal of Fish Biology 65, 1180-1184.

Bath, H. (1982). Beitrag zur Revalidation von Parablennius ruber (Valenciennes, 1836) mit kritschen Bemerkungen zur Gultigkeit der Gattung Pictiblennius Whitley 1930 (Pisces: Blenniidae). Senckenbergiana Biologica 62, 211-224.

Crowley, T. J. (1981). Temperature and circulation changes in the eastern North Atlantic during the last 150000 years: evidence from the planktonic foraminiferal record. Marine Micropaleontology 6, 97-129. 
Dias, J. A., Rodrigues, A. \& Magalhães, F. (1997). Evolução da linha de costa em Portugal, desde o último máximo glaciário até à actualidade: síntese dos conhecimentos. Estudos do Quaternário 1, 53-66.

Excoffier, L., Smouse, P. E. \& Quattro, J. M. (1997). Analysis of molecular variance inferred from metric distances among DNA haplotypes: application to human mitochondrial DNA restriction data. Genetics 131, 479-491.

Farris, J. S., Källersjö, M., Kluge, A. G. \& Bult, C. (1995). Testing significance of incongruence. Cladistics 10, 315-319.

Felsenstein, J. (1985). Confidence limits on phylogenies: an approach using the bootstrap. Evolution 39, 783-791.

Henriques, M., Lourenço, R., Almada, F., Calado, G., Gonçalves, D., Guillemaud, T., Cancela, M. L. \& Almada, V. C. (2002). A revision of the status of Lepadogaster lepadogaster (Teleostei: Gobiesocidae): sympatric subspecies or a long misunderstood blend of species? Biological Journal of the Linnean Society 76, 327-338.

Kröncke, I., Dippner, J. W., Heyen, H. \& Zeiss, B. (1998). Long-term changes in macrofaunal communities off Nordeney (East Frisia, Germany) in relation to climate variability. Marine Ecology Progress Series 167, 25-36.

Muss, A., Robertson, D. R., Stepien, C. A., Wirtz, P. \& Bowen, B. W. (2001). Phylogeography of Ophioblennius: the role of ocean currents and geography in reef fish evolution. Evolution 55, 561-572.

Nei, M. \& Kumar, S. (2000). Molecular Evolution and Phylogenetics. Oxford: Oxford University Press.

O'Brien, C. M., Fox, C. J., Planque, B. \& Casey, J. (2000). Climate variability and North Sea cod. Nature 404, 142.

Sambrook, E., Fritsch, F. \& Maniatis, T. (1989). Molecular Cloning. New York: Cold Spring Harbor Press.

Santos, R. S. (1987). Aspectos da ecologia e comportamento da fauna litoral dos Açores: I - Primeiras observações sobre o comportamento territorial e parental de Parablennius ruber (Valenciennes)(Pisces: Blennidae), com uma pequena nota sobre os embriões. Açoreana 6, 352-377.

Santos, R. S., Hawkins, S. J., Monteiro, L. R., Alves, M. \& Isidro, E. J. (1995). Marine research, resources and conservation in the Azores. Aquatic Conservation: Marine and Freshwater Ecosystems 5, 311-354.

Santos, R. S., Porteiro, F. M. \& Barreiros, J. P. (1997). Marine fishes of the Azores: annotated checklist and bibliography. Bulletin of the University of Azores Suppl. 1, 244.

Schneider, S., Roessli, D. \& Excoffier, L. (2000). ARLEQUIN, Version 2.000: A Software for Population Genetics Data Analysis. Geneva, Switzerland: University of Geneva.

Southward, A. J., Hawkins, S. J. \& Burrows, M. T. (1995). Seventy years' observations of changes in distribution and abundance of zooplankton and intertidal organisms in the western English Channel in relation to rising sea temperature. Journal of Thermal Biology 20, 127-155.

Swofford, D. L. (1998). PAUP: Phylogenetic Analysis Using Parsimony and Other Methods. Sunderland, MA: Sinauer Associates.

Thompson, J. D., Gibson, T. J., Plewniak, F., Jeanmougin, F. \& Higgins, D. G. (1997). The ClustalX windows interface: flexible strategies for multiple sequence alignment aided by quality analysis tools. Nucleic Acids Research 24, 4876-4882.

Valenciennes, A. (1836) De la famille des Gobiö̈des. Histoire Naturelle Des Poissons (eds Cuvier, G. \& Valenciennes, A.) i-xx, 14, 1-506, 2 pp.

Wirtz, P. (1998). Twelve invertebrate and eight fish species new to the marine fauna of Madeira, and a discussion of the zoogeography of the area. Helgolander Meeres Untersuchungen 52, 197-207.

Zander, C. D. (1973). Evolution of Blennioidei in the Mediterranean sea. Revue Travaux de L'Institut de Péches Maritimes 37, 215-221.

Zander, C. D. (1980). Zoogeography and speciation of Mediterranean blennioids (Perciformes, Pisces). In Journées de Etudes Systématiques et Biogéographiques de Mediterraneen C.I.E.S.M., pp. 13-38. Cagliari. 